\title{
Wheat Leaf Rust Severity as Affected by Plant Density and Species Proportion in Simple Communities of Wheat and Wild Oats
}

\author{
Thomas G. Pfleeger and Christopher C. Mundt
}

First author: U.S. Environmental Protection Agency, Western Ecology Division, 200 S.W. 35th Street, Corvallis, OR 97333; and second author: Department of Botany and Plant Pathology, 2082 Cordley Hall, Oregon State University, Corvallis 97331-2902.

Accepted for publication 31 March 1998.

\begin{abstract}
Pfleeger, T. G., and Mundt, C. C. 1998. Wheat leaf rust severity as affected by plant density and species proportion in simple communities of wheat and wild oats. Phytopathology 88:708-714.

While it is generally accepted that dense stands of plants exacerbate epidemics caused by foliar pathogens, there is little experimental evidence to support this view. We grew model plant communities consisting of wheat and wild oats at different densities and proportions and exposed these communities to Puccinia recondita to induce wheat leaf rust. Wild

ered by rust lesions. Seeding density rarely had a significant influence on rust severity, probably because of compensation due to increased tillering at low seeding densities. In contrast, increasing the proportion of wheat in mixtures with wild oats consistently increased wheat leaf rust severity. Regression parameters describing wheat leaf rust severity as a function of wheat seeding density did not differ significantly between pure wheat stands and wheat-wild oat mixtures and, thus, failed to support an effect of wild oats on wheat leaf rust other than through its competitive impact on wheat tiller density.
\end{abstract} oats was included because it is a common competitor of wheat and may act as a barrier to the dispersal of $P$. recondita spores among wheat plants. Disease severity was estimated as percentage of wheat flag leaves cov-
Additional keywords: Avena fatua, Triticum aestivum.
According to Burdon and Chilvers (10), the concept that growing plants in dense stands contribute to severe epidemics is an accepted axiom with few experimental data to support it. They further questioned the contribution of density of resistant plants in mixed stands on disease control, as opposed to changes in density of susceptible plants. Since then, some progress has been made in determining the effects of plant density on disease severity $(3,5)$. The difficulty in determining the effects of plant density on disease severity is due, in part, to the diversity of life strategies that plants and their pathogens exhibit, making it difficult to make generalizations concerning plant disease and host-nonhost densities. For example, the severity of rosette disease in groundnut (Arachis hypogea) is negatively correlated with plant density $(1,16)$. The causal agent of groundnut rosette disease is an aphid (Aphis craccivora)-transmitted virus. The flying aphids preferentially land on plants associated with surrounding bare ground (16). In contrast, the spread of white rot in onions (Allium cepa) by the fungal pathogen Sclerotium cepivorum is positively correlated with plant density and can be controlled by spacing the host to eliminate root contact between adjacent plants (27).

In an attempt to clarify the effect of plant density on disease, Burdon and Chilvers (10) classified plant-pathogen interactions into categories based on a temporal scale. They further subdivided each of these three defined time scales (short, medium, and long) by type of pathogen (virus or fungus) and type of dispersal (soil-

Corresponding author: T. G. Pfleeger; E-mail address: tom@mail.cor.epa.gov

Mention of trade names or commercial products does not constitute endorsement or recommendation for use by the U.S. Environmental Protection Agency.

Publication no. P-1998-0511-01R

This article is in the public domain and not copyrightable. It may be freely reprinted with customary crediting of the source. The American Phytopathological Society, 1998 borne, airborne, or splash-dispersed). Even with this detailed analysis, they were able to conclude nothing more specific than the suggestion that host density plays an important role in the hostpathogen-environment triangle $(10)$. Others $(3,5)$ have suggested, based on these and more recent data, that there is a tendency for viral-mediated diseases to decrease with increasing host density and for fungal-mediated diseases to increase with increasing host density. However, it is also becoming clearer that host-nonhost density effects may be disease specific, and even temporally and spatially specific. For example, steep spore-deposition gradients will intensify disease locally, but slow the spread of disease, whereas pathogens with shallow gradients will intensify more slowly, but spread more rapidly (18). In addition, the effects of plant density have not yet been evaluated for many diseases (5).

Planting mixtures of plant genotypes, species, or both for control of herbivores and pathogens have been and continue to be practiced by aboriginal peoples $(25,32)$. Mixtures are also becoming an increasing part of modern agriculture, because in some cases, they reduce both the incidence and rate of increase of disease (35). Several workers have suggested that mixtures will be most effective against pathogens with shallow spore-dispersal gradients and for hosts with small plants $(18,24)$. However, intercropping can increase, decrease, or have no effect on disease severity (5). For example, Van Rheenen et al. (34), working with a bean-maize intercrop at seven sites over 5 years in Kenya, found that, while 8 of 10 bean diseases were likely to be more severe in a monocrop than in the intercrop, there was always the exception in which a given disease was worse or not affected in the intercrop. The success of intercropping systems for disease control is dependent to a large degree on the interactions between the amount and location of each crop's tissues, pathogen dispersal properties, microclimatic conditions, and interspecific competition (5).

In an attempt to clarify the importance of plant density and species proportion on cereal rust severity, we grew artificial communities consisting of spring wheat (Triticum aestivum L.) and wild 
oats (Avena fatua L.) at different densities and proportions and exposed these communities to the wheat leaf rust pathogen Puccinia recondita Rob. ex. Desm. This system was chosen because wheat is a valuable agricultural crop, the interaction between wheat and $P$. recondita is fairly well understood, and wild oats is a commonly occurring competitor of wheat. We hypothesized that increased host (wheat) density in monocultures and increased host proportion in mixtures would result in increased wheat leaf rust.

\section{MATERIALS AND METHODS}

Experimental plots were located at the Oregon State University (OSU) Botany and Plant Pathology Field Laboratory immediately east of Corvallis, OR. Different fields (approximately 0.2 ha) were used for each year (1995 and 1996). No grain crops had been grown in the fields for several years prior to this experiment. The Chehalis silty clay loam soil was prepared using standard agricul-

\section{5}
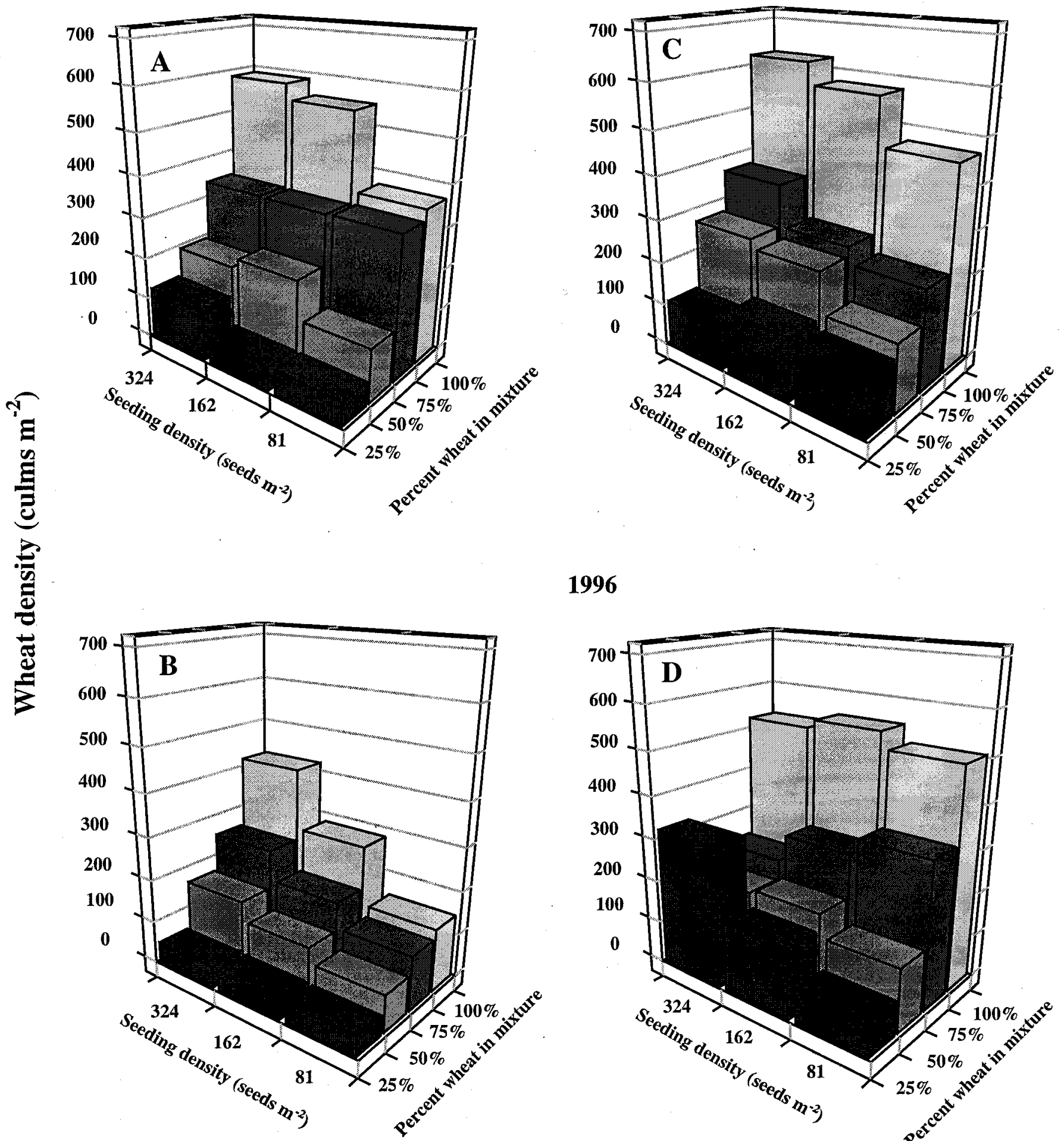

1996

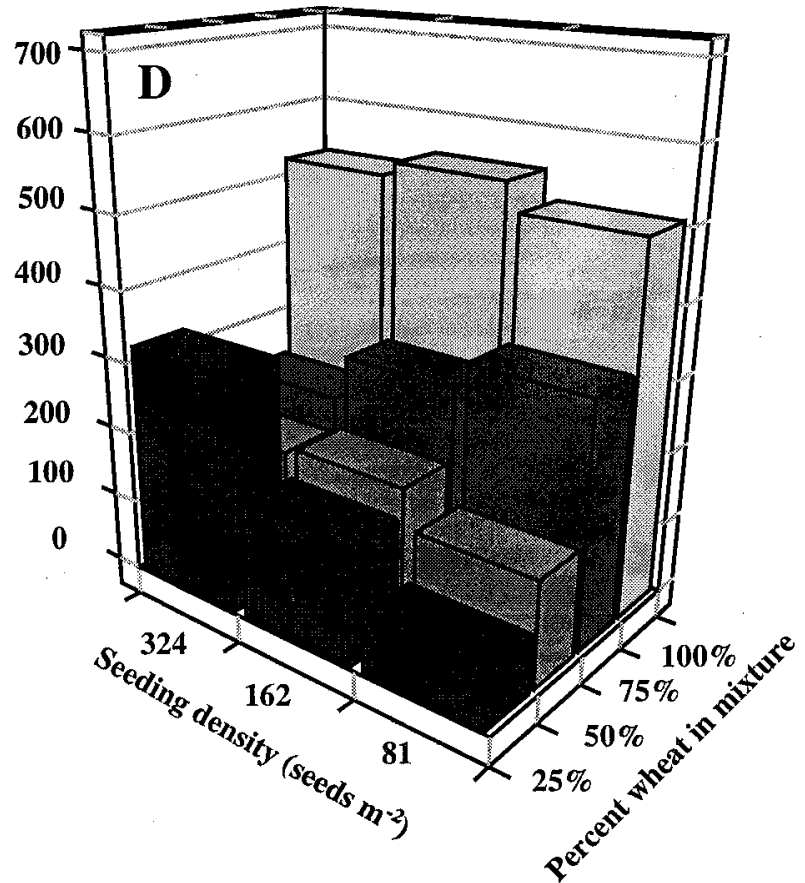

Fig. 1. Plot of wheat culm number (flag leaf number) on seeding density of two cultivars (Twin and Penawawa) in monocultures and wheat-wild oats mixtures. Each bar is the mean of four replicate plots planted at one of four proportions (wheat/wild oats $=100: 0,75: 25,50: 50$, and 25:75) for each of three seeding densities (81, 162, and 324 seeds per $\mathrm{m}^{2}$ ). A, ‘Twin' wheat 1995; B, ‘Twin' wheat 1996; C, 'Penawawa' wheat 1995; and D, 'Penawawa' wheat 1996. 
tural practices in the fall prior to spring planting. Several days prior to planting (28 March 1995 and 16 March 1996), the field was sprayed with the herbicide glyphosate. A standard soil nutrient test (OSU Central Analytical Laboratory) indicated that nitrogen levels were below recommended concentrations for growing wheat. Nitrogen (46-0-0) as urea was added twice over the 1995 growing season at a rate of $56 \mathrm{~kg} / \mathrm{ha}$ for a total of $112 \mathrm{~kg} / \mathrm{ha}$, and three times in 1996 , once at $56 \mathrm{~kg} / \mathrm{ha}$ and twice at $45 \mathrm{~kg} / \mathrm{ha}$, for a total of $146 \mathrm{~kg} / \mathrm{ha}$. Bromoxynil (Buctril) was sprayed postemergence to control broadleaf plants. The fields were irrigated with overhead sprinklers three times each year in June and early July.

The experiment was arranged in a randomized complete block design with four replicates consisting of $301.2 \times 3-\mathrm{m}$ plots. Two commercial, economically important cultivars of spring wheat (Twin and Penawawa) and wild oats (A. fatua L.) were planted with a small plot grain drill at three densities of 81,162 , and 324 germinable seeds per $\mathrm{m}^{2}$ and at five proportions (100:0, 75:25, 50:50, 25:75, and 0:100) of wheat/wild oats. A total of 24 cultivar
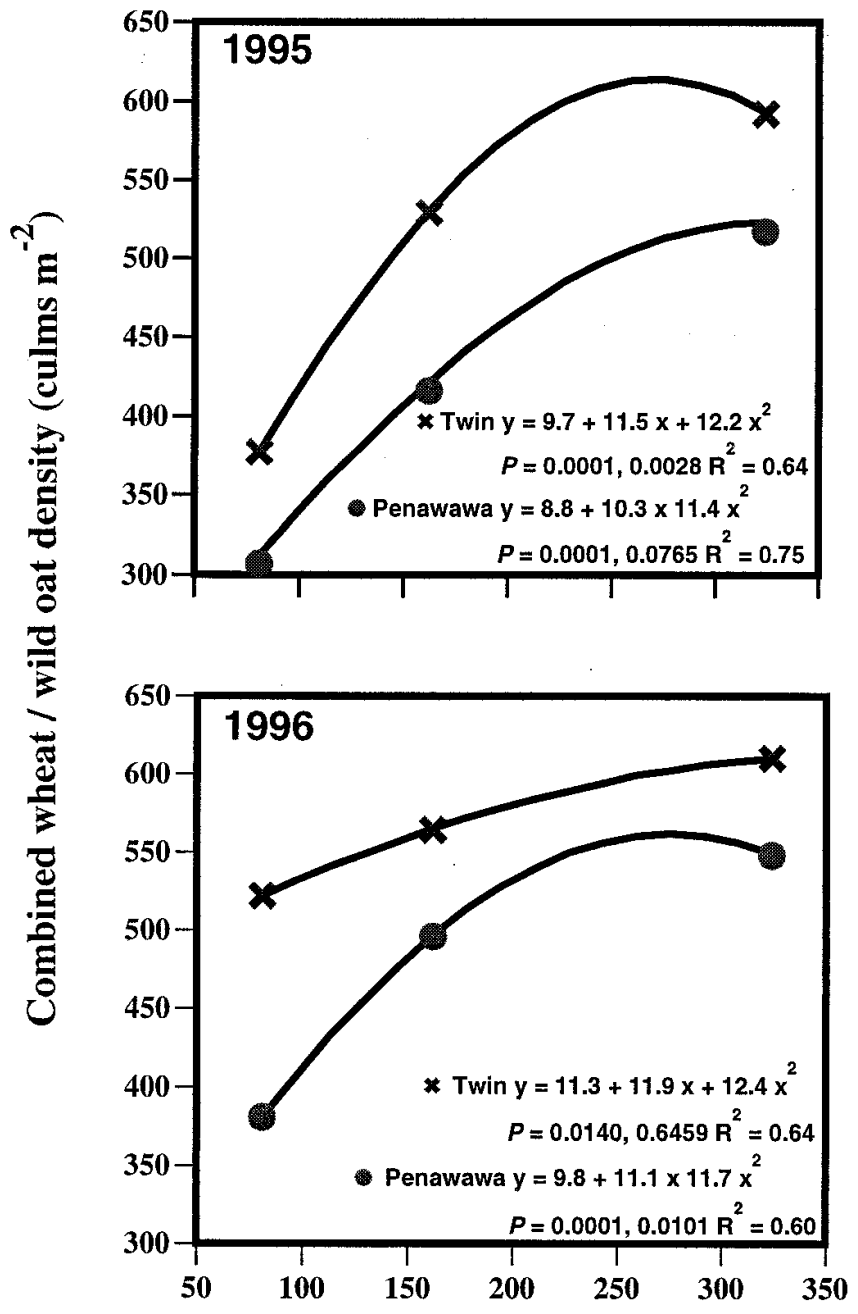

\section{Seeding density (seeds $\mathrm{m}^{-2}$ )}

Fig. 2. Regression of combined wheat and wild oats culm number on combined seeding density of wheat (cultivar Twin or Penawawa) in monocultures and wheat-wild oats mixtures. Regressions were performed on transformed number of culms per $\mathrm{m}^{2}$ (square root) and the data were back-transformed for plotting. Each point is the mean of 16 data points: four replicate plots planted at four proportions (wheat/wild oats $=100: 0,75: 25,50: 50$, and 25:75) for each of three seeding densities $\left(81,162\right.$, and 324 seeds per $\left.\mathrm{m}^{2}\right) . R^{2}$ values were calculated from the entire data set for each cultivar by year. $P$ values are from $F$ tests to determine if the model had a significant linear component, a significant nonlinear component, or both. $\times$ density $\times$ proportion combinations were used for disease analysis; the $100 \%$ wild oats plots were excluded. No plot contained both wheat varieties. Between rows of plots, a 1.2-m-wide buffer strip of barley (Hordeum vulgare L. cv. Steptoe in 1995) or triticale ( $\times$ Triticosecale Wittmack cv. Celia in 1996) was planted to reduce the spread of spores between plots.

The wheat cultivar Twin is susceptible to wheat leaf rust, whereas 'Penawawa' is moderately resistant and wild oats is immune. Wild oats was chosen because it is a competitor of cultivated wheat in western Oregon and many other wheat-growing areas and may act as a barrier to the dispersal of $P$. recondita spores among wheat plants. Several sources of wild oats seed were tested for germination. Seed collected as screenings from a grain elevator in Alberta, Canada, was used, as it had the highest germination rate. Wheat also was tested for germination prior to planting, and seeding rates for both species were adjusted to produce densities of 81,162 , and 324 germinable seeds per $\mathrm{m}^{2}$.

Uredospores of $P$. recondita were collected from greenhouseinoculated wheat and mixed with talc powder prior to field application. Plots were inoculated with uredospores using a hand-held duster in the early morning or late evening during periods of low wind to minimize drifting. Generalized inoculation was used to diminish sampling difficulties associated with focal point inoculation and because generalized inoculation more closely simulates the natural inoculation of wheat with wheat leaf rust in western Oregon. In 1995, a total of $11.2 \mathrm{~g}$ of uredospores was applied on 3 and 4 June. In 1996, a total of $15 \mathrm{~g}$ was applied over 7 days from 5 May to 13 June. More spores and days of application were required in 1996 because cold temperatures during May prevented disease establishment. Inoculation was started earlier in 1996 to assure the disease was established during flag leaf emergence.

Disease severity readings were taken on 18 to 19 July 1995 and on 27 to 28 June and 10 to 11 July 1996 by estimating the percentage of leaf area covered by pustules and associated chlorosis for 10 randomly chosen wheat flag leaves in each plot. One hundred percent disease was defined as a leaf blade covered completely with pustules and associated chlorosis. All disease readings were performed prior to each assessment by T. Pfleeger, following training using the DISTRAIN computer program (33). The final proportions of wheat and wild oats in the mixtures were determined by counting the number of culms of each species from a $0.25-\mathrm{m}^{2}$ subplot in the center of each plot at harvest.

Data were initially compiled in a computer spreadsheet for preliminary statistical measures. Final statistical analyses were performed using the statistical analysis system (SAS Institute Inc., Cary, NC). Four plots were lost to planting and seed mixing errors in 1995.

Analysis of variance (ANOVA) for disease severity was performed using the SAS general linear models procedure (PROC GLM) to test for cultivar, seeding density, species proportion main effects, and all possible interactions among these main effects. The percent disease readings were transformed using the arcsin of the square root transformation to better meet the homogeneity of variance and normality assumptions. One outlier was removed from the analysis for the June 1996 data, although the ANOVA with and without the outlier indicated little difference in results. PostANOVA polynomial contrasts were used to describe the effects of density, proportion, and their interaction on rust severity.

Regression of wheat leaf rust severity on measured wheat density was performed on two subsets of the data that consisted of (i) plots containing $100 \%$ wheat, but planted at different densities, and (ii) mixed wheat-wild oats plots planted at one seeding density $\left(324\right.$ seeds per $\mathrm{m}^{2}$ ). These regressions were used to differentiate between the effects of density of susceptible plants versus the barrier effects of resistant plants (interception of spores by nonhost species). Tests for equality of regression lines and $\mathrm{y}$ intercepts were performed on the two subsets by using $F$ tests. 


\section{RESULTS}

Generally, there was an increase in the number of wheat culms or flag leaves with increasing wheat seeding density in plots containing $100 \%$ wheat, indicating that density of resources for pathogen multiplication increased with seeding density (Fig. 1). Increasing the proportion of wild oats in mixed stands with wheat decreased the number of culms per wheat plant, indicating a negative competitive effect of wild oats on wheat (Fig. 1). Regressions of wheat and wild oat culm number on total seeding density showed that, while overall culm density was greater at higher seeding densities, there was not a 1-to-1 ratio or even a linear relation between planting density and the resulting number of culms (Fig. 2).

Wheat leaf rust severity was not significantly affected by seeding density. However, disease severity was significantly impacted by the proportion of wheat in wheat-wild oats mixtures for both July data sets (Table 1). The wheat cultivar Twin was significantly more susceptible than 'Penawawa' for both years and at all samplings (Table 1, Fig. 3). Generally, there was a lack of interactions between experimental treatments. Only 2 of the 12 interactions including density, proportion, or both were significant (Table 1).

The significant interaction between proportion and cultivar in June 1996, along with the known differential sensitivity of each cultivar to wheat leaf rust, indicated the need for separate ANOVAs by cultivar (Table 2). At the cultivar level, density of wheat was again not a significant factor in determining rust severity, whereas proportion of wheat in mixture with wild oats was always a significant factor in the July data sets (Table 2). The exception was the cultivar Twin in July 1996, when density had a significant effect (Table 2). The June 1996 data indicated a difference based on cultivar (Table 1), in which seeding density and proportion were significant factors influencing disease severity for 'Twin', but not for 'Penawawa' (Table 2, Fig. 3).

There was often a positive and linear relationship between percent rust severity and wheat proportion (Table 2). In some cases, there was also a significant nonlinear component, but in all of these cases, the nonlinear component was less significant than the linear component (Table 2). The proportion $\times$ density interaction reported for combined cultivars (Table 1) in 1995 was not present when

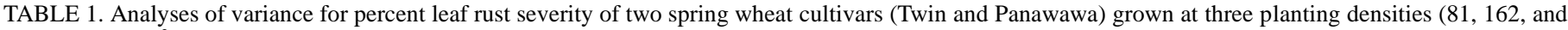
324 seeds per $\mathrm{m}^{2}$ ) in both pure stands and in mixture with wild oats at four proportions (wheat/wild oats $=100: 0,75: 25,50: 50$, and $\left.25: 75\right)^{\mathrm{a}}$

\begin{tabular}{|c|c|c|c|c|c|c|c|c|c|}
\hline \multirow[b]{2}{*}{ Source of variation } & \multicolumn{3}{|c|}{ July 1995} & \multicolumn{3}{|c|}{ June $1996^{\mathrm{b}}$} & \multicolumn{3}{|c|}{ July 1996} \\
\hline & df & $\mathrm{MS}^{\mathrm{c}}$ & $P>F$ & df & MS & $P>F$ & $\mathrm{df}$ & MS & $P>F$ \\
\hline Block & 3 & 0.0288 & 0.0172 & 3 & 0.0629 & 0.0009 & 3 & 0.1259 & 0.0001 \\
\hline Cultivar & 1 & 4.194 & 0.0001 & 1 & 0.0681 & 0.012 & 1 & 0.8789 & 0.0001 \\
\hline Density & 2 & 0.0145 & 0.1689 & 2 & 0.0177 & 0.184 & 2 & 0.0147 & 0.3901 \\
\hline Cultivar $\times$ density & 2 & 0.0128 & 0.2074 & 2 & 0.015 & 0.2372 & 2 & 0.0263 & 0.188 \\
\hline Proportion & 3 & 0.1018 & 0.0001 & 3 & 0.0172 & 0.1791 & 3 & 0.2149 & 0.0001 \\
\hline Cultivar $\times$ proportion & 3 & 0.0055 & 0.5577 & 3 & 0.0318 & 0.0316 & 3 & 0.0059 & 0.7643 \\
\hline Density $\times$ proportion & 6 & 0.0218 & 0.019 & 6 & 0.0085 & 0.5458 & 6 & 0.0102 & 0.6768 \\
\hline Cultivar $\times$ density $\times$ proportion & 6 & 0.0089 & 0.3592 & 6 & 0.0085 & 0.551 & 6 & 0.0112 & 0.6285 \\
\hline Error & 65 & 0.0079 & & 68 & 0.0102 & & 69 & 0.0514 & \\
\hline Total & 91 & & & 94 & & & 95 & & \\
\hline$R^{2}$ & 0.90 & & & 0.45 & & & 0.68 & & \\
\hline
\end{tabular}

a Analyses were conducted on the arcsin of square root-transformed values.

b One outlier was removed from the June 1996 data.

c Mean square.

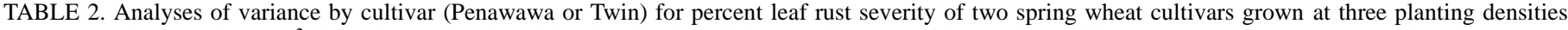
$\left(81,162\right.$, and 324 seeds per $\left.\mathrm{m}^{2}\right)$ in both pure stands and in mixture with wild oats at four proportions $(\text { wheat/wild oats }=100: 0,75: 25,50: 50 \text {, and } 25: 75)^{\text {a }}$

\begin{tabular}{|c|c|c|c|c|c|c|c|c|c|}
\hline \multirow[b]{2}{*}{ Cultivar, source of variation } & \multicolumn{3}{|c|}{ July 1995} & \multicolumn{3}{|c|}{ June $1996^{b}$} & \multicolumn{3}{|c|}{ July 1996} \\
\hline & $\mathrm{df}$ & $\mathrm{MS}^{\mathrm{c}}$ & $P>F$ & df & MS & $P>F$ & $\mathrm{df}$ & MS & $P>F$ \\
\hline \multicolumn{10}{|l|}{ Penawawa $^{\mathrm{d}}$} \\
\hline Block & 3 & 0.0164 & 0.0144 & 3 & 0.0345 & 0.0756 & 3 & 0.0949 & 0.0231 \\
\hline Density & 2 & 0.0045 & 0.3393 & 2 & 0.0002 & 0.9869 & 2 & 0.0215 & 0.4467 \\
\hline Proportion & 3 & 0.0373 & 0.0001 & 3 & 0.0087 & 0.5988 & 3 & 0.1088 & 0.0133 \\
\hline Linear & 1 & 0.0613 & 0.0005 & 1 & 0.0004 & 0.8566 & 1 & 0.2986 & 0.0019 \\
\hline Nonlinear & 2 & 0.0231 & 0.0073 & 2 & 0.0128 & 0.4027 & 2 & 0.0138 & 0.5949 \\
\hline Density $\times$ proportion & 6 & 0.0055 & 0.2577 & 6 & 0.0064 & 0.8266 & 6 & 0.0101 & 0.8831 \\
\hline Error & 31 & 0.004 & & 32 & 0.0137 & & 33 & 0.0262 & \\
\hline Total & 45 & & & 46 & & & 47 & & \\
\hline$R^{2}$ & 0.63 & & & 0.28 & & & 0.45 & & \\
\hline \multicolumn{10}{|l|}{ Twine } \\
\hline Block & 3 & 0.0156 & 0.303 & 3 & 0.0472 & 0.0004 & 3 & 0.051 & 0.0001 \\
\hline Density & 2 & 0.023 & 0.1708 & 2 & 0.033 & 0.0089 & 2 & 0.0193 & 0.0159 \\
\hline Proportion & 3 & 0.0714 & 0.0029 & 3 & 0.0407 & 0.0011 & 3 & 0.112 & 0.0001 \\
\hline Linear & 1 & 0.1984 & 0.0003 & 1 & 0.097 & 0.0003 & 1 & 0.3028 & 0.0001 \\
\hline Nonlinear & 2 & 0.0062 & 0.6065 & 2 & 0.0125 & 0.1425 & 2 & 0.0165 & 0.0274 \\
\hline Density $\times$ proportion & 6 & 0.0349 & 0.0922 & 6 & 0.0101 & 0.1576 & 6 & 0.0113 & 0.0277 \\
\hline Error & 33 & 0.0041 & & 33 & 0.006 & & 33 & & 0.004 \\
\hline Total & 47 & & & 47 & & & 47 & & \\
\hline$R^{2}$ & 0.81 & & & 0.66 & & & 0.81 & & \\
\hline
\end{tabular}

\footnotetext{
a Analyses were conducted on the arcsin of square root-transformed values.

b One outlier was removed from the June 1996 'Penawawa' data.

c Mean square.

d 'Penawawa' is moderately resistant to wheat leaf rust.

e 'Twin' is susceptible to wheat leaf rust.
} 
cultivars where analyzed separately, except for 'Twin' in July 1996 (Table 2).

Leaf rust severity increased with the proportion of wheat in all cases, except the June 1996 data for 'Penawawa' (Fig. 3). The proportion of wheat in mixtures with wild oats was pooled across different seeding densities for regression analysis (Fig. 3), because density was rarely significant and there was an absence of significant density by proportion interactions in the 1996 data, and because the proportion mean square was much larger than the density by proportion interaction mean square in the 1995 data set (Table 1). As expected, the slopes and y intercepts for the susceptible cultivar Twin were greater than for the more resistant cultivar
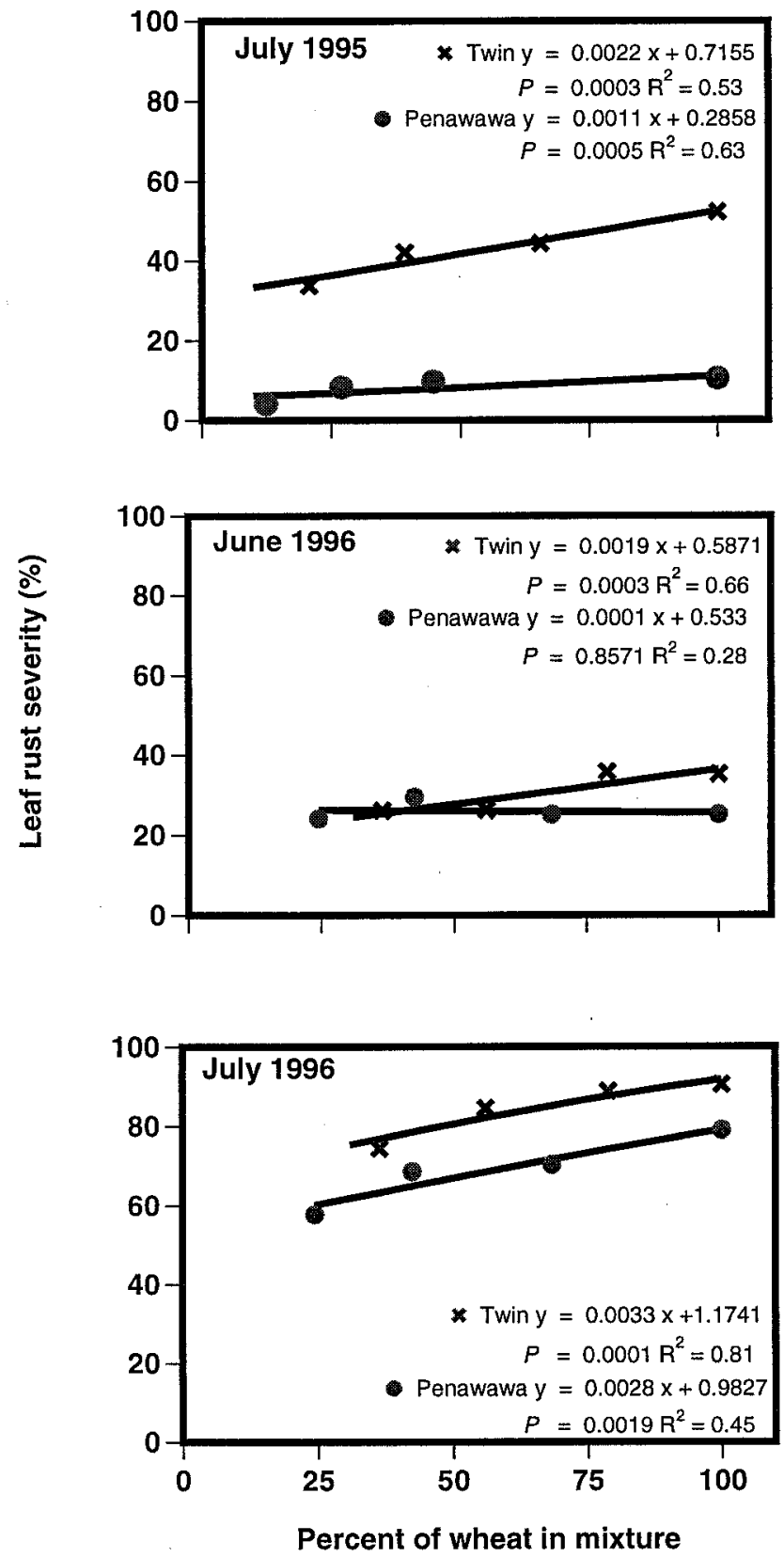

Fig. 3. Regression of wheat leaf rust severity on proportion of wheat culms of two cultivars (Twin and Penawawa) in wheat monocultures and wheatwild oats mixtures at harvest. Regressions were performed on transformed percent disease severity measurements (arcsin of the square root) and the data were back-transformed for plotting. Each point is the mean of 12 data points: four replicate plots planted at three seeding densities $(81,162$, and 324 seeds per $\mathrm{m}^{2}$ ) for each of four proportions (wheat/wild oats $=100: 0$, $75: 25,50: 50$, and 25:75). $R^{2}$ values were calculated from the entire data set for each cultivar by date. $P$ values are from $F$ tests to determine if slopes were significantly different from zero.
Penawawa (Fig. 3). Slopes increased from June to July 1996 for both cultivars.

There was no evidence to suggest that the barrier effect of wild oats in mixtures was significant in decreasing disease severity. This was tested using regression analysis to determine if the effects of differing culm density in pure stands were significantly different from the effects of differing culm density (changes in proportion) of wheat in wheat-wild oats mixtures (Table 3 ). In no case was there statistical evidence to suggest that the slopes for rust severity on culm number per unit area were different for density versus proportion treatments (Table 3), and in only one case ('Penawawa', July 1996) was there evidence that the regression lines were not equivalent (Table 3 ).

\section{DISCUSSION}

Host density. Planting density did not affect rust severity significantly, even though the highest seeding density was $4 \times$ the lowest. This lack of significance probably can be explained by the plastic response of plants in response to space (20) and, in particular, the ability of wheat to make compensatory growth in response to variable growing conditions (19). The plastic growth of plants, particularly annuals, is a confounding factor with density treatments, as density remains fixed while individual plants change by growing in response to their environment. For example, the range in density of harvested culms among treatments was much smaller (1.1 to $1.9 \times)$ than the fourfold range in initial seeding rates (Figs. 1 and 2). This response held regardless of the proportion of wheat in a mixture (Fig. 1). However, wheat culm density changed the least with increasing seeding density in the mixed plots having the lowest percentages of wheat, probably due to the competitive effect of wild oats on wheat.

A wider range in seeding densities than we used might help clarify the effects of density on rust severity, but at high densities self-thinning may occur $(14,36)$. Darwinkel $(14,15)$ planted winter wheat at densities varying up to 160 -fold, but only a 4.3 - to 5.7fold increase in culm number at harvest was found due to an increased number of culms per plant with decreased planting density. Shah et al. (28) planted winter wheat at two moderate densities (84 and $168 \mathrm{~kg} / \mathrm{ha}$ ) and found no significant difference in grain yield when seeded early. Yields differed with later-planted wheat, and they attributed this difference to the greater tillering ability of early-planted wheat.

Gassner (cited by Chester [12]) sowed wheat from 30 to 160 $\mathrm{kg} / \mathrm{ha}$ and found no difference in the amount of wheat leaf rust, because the wheat had a tendency to regulate its stand to a uniform density. When artificial density gradients were maintained, he still found no correlation between plant density and disease severity. In contrast, Russian scientists (Smitikova-Rusakova; cited by Chester [12]) did similar controlled-density studies with wheat and found that rust intensity increased with density. Gassner (cited by Chester [12]) conducted his studies in Uruguay, where he suggested that microclimatic conditions were conducive to rust infection at all wheat densities, whereas optimal conditions for rust development were met only in the higher densities of wheat in Russia (12).

Since the early work described above, others $(4,7,11,31)$ have suggested that microclimatic changes resulting from higher plant densities has lead to improved conditions for disease development. This, in part, may explain the year-to-year differences seen in epidemic length and severity (Fig. 3), because the 1995 crop was less productive and probably had microclimatic differences less conducive to disease development than the 1996 field environment. Thus, proximity of plants may not be the only cause of positive correlations between plant density and disease severity. However, dense stands also produce higher levels of competition and the subsequent loss of leaf tissue lower in the canopy, which could otherwise become infected $(7,12,29)$. In addition, plant nutritional status 
probably differed with density, and host nutritional levels can have a significant impact on disease susceptibility and progression (12).

Species proportion. The relation between disease severity and wheat proportion was linear and positively correlated for both transformed and back-transformed scales. A similar result was found for stripe rust, caused by $P$. striiformis, in wheat cultivar mixtures (2). Leonard (21) developed an analytical model, based on the biology of rust pathogens, to predict the impact on disease of the proportion of susceptible plants in mixtures of resistant and susceptible plants. This model predicts a logarithmic relationship between the proportion of susceptible plants in mixture and the rate of epidemic development, a relationship that is supported by experimental studies $(9,21,22)$. As the relationship between epidemic rate and disease severity is not linear for a polycyclic epidemic, it is not surprising that the proportion of susceptible to nonsusceptible plants in a population has a different impact on these two parameters. Regardless, treatments with the lowest proportion of susceptible plants had the least disease in our study, as is usually the case for rusts and mildews of small grains $(6,23,35)$.

Mechanisms of nonhost influence. The question remains as to the role wild oats played in reducing wheat leaf rust severity. Did the oats act as a physical barrier to the movement of inoculum, or did it merely occupy space and effectively change the density of wheat? As the proportion of wheat increases in a series of mixedspecies plots planted at the same combined total density, the density of wheat increases, while the barrier effect provided by the nonhost species decreases. If the regression lines from the two subsets of data (Table 3) are the same, then the density component of proportion would be the most important factor. In contrast, if the slope from the changing proportion data is steeper, then there could be a significant barrier effect from the wild oats. We found no significant difference between the regression lines, suggesting that nonhost tissue was not an effective barrier to inoculum movement. However, the variability associated with our measurements was quite high, and larger sample sizes are needed to clarify the issue. In addition, it is possible that competitive interactions between wheat and wild oats altered the susceptibility of wheat to rust, as was suggested for wheat cultivar mixtures infected by stripe rust (17).

While at the end of the growing season wild oats is much taller than wheat, wild oats height extension does not occur until wheat has already set seed. Therefore, the effect of height differences between wild oats and wheat are probably limited to later epidemic stages that would impact wheat seed size (as other yield compo- nents will already have been established), and to potential dispersal to other, later-maturing fields.

Burdon and Chilvers $(8,9)$ have suggested that a decrease in disease caused by fungal pathogens in mixed-species assemblages is not a response to the nonhost interception of airborne inoculum, but rather to a reduction in density of the host. Chin and Wolfe (13), in an elegant experiment to separate effects of density, proportion, and induced resistance in cultivar mixtures, were never able to quantify the difference between density and proportion. They concluded that the effect of cultivar mixtures could be partitioned into three categories: (i) when plants were small, changes in plant density controlled disease levels; (ii) as plants grew, the presence of resistant cultivars increased in importance by acting as barriers to inoculum movement; and (iii) later in the season, differentially susceptible cultivars helped control disease by allowing induced resistance to occur. In addition, changes in plant competition and microclimate are also likely to change with host density. For example, a species that is competitively superior might have more resources available for obligate pathogen infection when grown in mixture than in monoculture at the same density.

As suggested by Power (26), the general difference attributed to insect-vectored pathogens versus wind-dispersed fungal pathogens in relation to host density may be due to active selection of host plants by a limited number of insects. In contrast, fungal pathogens passively disperse spores and spores may be transported to plant genotypes on which they cannot reproduce. When nonhost species acquire significant space, they reduce host species densities, act as traps for inoculum, or both. In doing so, they may have an important role in natural communities by decreasing the severity of some diseases. Thus, plant diversity may help to sustain rare but susceptible species in plant communities, in contrast to some herbivore-plant interactions, in which a plant's susceptibility to herbivory can increase if surrounded by diverse, acceptable host plants when attacked by polyphagous insects (30). Therefore, rarity could be a more successful strategy for plants to escape fungal pathogens than to escape herbivores.

The conceptual problem of trying to attribute part of wheat leaf rust progression to host density, proportion, or both is that neither term is adequately inclusive to explain the dynamic nature of the process. Wheat leaf rust progression might be better considered as space acquisition by the host. Initially, plant hosts functionally exist in two-dimensional space, in which the number of seedlings is a meaningful way to interpret the potential for infection. Later, as

TABLE 3. y Intercepts and slopes for regression of percent left rust severity on density of wheat culms (culms per $\mathrm{m}^{2}$ ) in pure stands ${ }^{\mathrm{a}}$ and in wheat-wild oats mixtures $^{\mathrm{b}}$ grown at Corvallis, OR, during 1995 and $1996^{\mathrm{c}}$

\begin{tabular}{|c|c|c|c|c|c|c|c|c|}
\hline Date & Cultivar & Plot type & $\mathrm{y}$ Intercept & $\mathrm{SE}^{\mathrm{d}}$ & Slope & $\mathrm{SE}^{\mathrm{e}}$ & $P>F^{\mathrm{f}}$ & $P>F^{\mathrm{g}}$ \\
\hline \multirow[t]{4}{*}{ July 1995} & \multirow[t]{2}{*}{ Penawawa } & Mixed stand & 0.249 & 0.038 & 0.0008 & 0.0009 & \multirow[t]{2}{*}{0.89} & \multirow[t]{2}{*}{0.73} \\
\hline & & Pure stand & 0.266 & 0.044 & 0.0009 & 0.0005 & & \\
\hline & \multirow[t]{2}{*}{ Twin } & Mixed stand & 0.740 & 0.088 & -0.0012 & 0.0015 & \multirow[t]{2}{*}{0.24} & \multirow[t]{2}{*}{0.17} \\
\hline & & Pure stand & 0.692 & 0.135 & 0.0009 & 0.0010 & & \\
\hline \multirow[t]{4}{*}{ June 1996} & \multirow[t]{2}{*}{ Penawawa } & Mixed stand & 0.508 & 0.083 & 0.0002 & 0.0012 & \multirow[t]{2}{*}{0.77} & \multirow[t]{2}{*}{0.84} \\
\hline & & Pure stand & 0.608 & 0.190 & -0.0003 & 0.0013 & & \\
\hline & \multirow[t]{2}{*}{ Twin } & Mixed stand & 0.529 & 0.049 & 0.0008 & 0.0006 & \multirow[t]{2}{*}{0.43} & \multirow[t]{2}{*}{0.58} \\
\hline & & Pure stand & 0.396 & 0.127 & 0.0015 & 0.0008 & & \\
\hline \multirow[t]{4}{*}{ July 1996} & \multirow[t]{2}{*}{ Penawawa } & Mixed stand & 0.849 & 0.093 & 0.0006 & 0.0013 & \multirow[t]{2}{*}{0.23} & \multirow[t]{2}{*}{0.03} \\
\hline & & Pure stand & 1.363 & 0.211 & -0.0019 & 0.0015 & & \\
\hline & \multirow[t]{2}{*}{ Twin } & Mixed stand & 1.025 & 0.048 & 0.0017 & 0.0005 & \multirow[t]{2}{*}{0.43} & \multirow[t]{2}{*}{0.70} \\
\hline & & Pure stand & 1.108 & 0.125 & 0.0009 & 0.0008 & & \\
\hline
\end{tabular}

\footnotetext{
${ }^{a}$ Wheat seeded at densities of 81,162 , and 324 seeds per $\mathrm{m}^{2}$.

b Wheat-wild oats mixtures seeded at a combined density of 324 seeds per $\mathrm{m}^{2}$ at four proportions (wheat/wild oats $=100: 0,75: 25,50: 50$, and 25:75).

c Analyses were conducted on the arcsin of square root-transformed values.

d Standard error of the estimates for the y intercept.

e Standard error of the estimates for slope.

f Testing the hypothesis $\mathrm{H}_{\mathrm{o}}$ : regression slopes for pure and mixed stands are equal, using an $F$ test.

$\mathrm{g}$ Testing the hypothesis $\mathrm{H}_{\mathrm{o}}$ : regression lines (i.e., joint test for equal intercepts and equal slopes) for pure and mixed stands are equal, using an $F$ test.
} 
plants grow and occupy three-dimensional space, inoculum is not limited to landing on bare ground or seedlings, but can also be intercepted by nonhost tissue. However, locally, inoculum may be so plentiful that nonhost interception is insignificant. At a larger spatial scale, wheat leaf rust progression across the landscape is additionally influenced by such factors as the distribution of infected tissue, its relation to prevailing winds, and changes in wind speed at the source and potential infection sites.

\section{ACKNOWLEDGMENTS}

The information in this article has been funded by the United States Environmental Protection Agency (EPA). It has been subjected to the Agency's peer and administrative review, and it has been approved for publication as an EPA document. We thank M. da Luz and R. Hayes for technical assistance; H. Lee for statistical support; and L. Tate for field management.

\section{LITERATURE CITED}

1. A'Brook, J. 1968. The effect of plant spacing on the numbers of aphids trapped over the groundnut crop. Ann. Appl. Biol. 61:289-294.

2. Akanda, S. I., and Mundt, C. C. 1996. Effects of two-component wheat cultivar mixtures on stripe rust severity. Phytopathology 86:347-353.

3. Augspurger, C. K. 1989. Impact of pathogens on natural plant populations. Pages 413-433 in: Plant Population Ecology. A. J. Davy, M. J. Hutchings, and A. R. Watkinson, eds. Blackwell Scientific Publications, Oxford.

4. Berger, R. D. 1975. Disease incidence and infection rates of Cercospora apii in plant spacing plots. Phytopathology 65:485-487.

5. Boudreau, M. A., and Mundt, C. C. 1997. Ecological approaches to disease control. Pages 33-62 in: Environmentally Safe Approaches to Crop Disease Control. N. A. Rechcigl and J. E. Rechcigl, eds. CRC Press, Boca Raton, FL.

6. Browning, J. A., and Frey, K. J. 1969. Multiline cultivars as a means of disease control. Annu. Rev. Phytopathol. 7:355-382.

7. Burdon, J. J., and Chilvers, G. A. 1976. Controlled environment experiments on epidemics of barley mildew in different density host stands. Oecologia 26:61-72.

8. Burdon, J. J., and Chilvers, G. A. 1976. Epidemiology of Pythium-induced damping-off in mixed species stands. Ann. Appl. Biol. 82:233-240.

9. Burdon, J. J., and Chilvers, G. A. 1977. Controlled environment experiments on epidemic rates of barley mildew in different mixtures of barley and wheat. Oecologia 28:141-146.

10. Burdon, J. J., and Chilvers, G. A. 1982. Host density as a factor in plant disease ecology. Annu. Rev. Phytopathol. 20:143-166.

11. Burdon, J. J., Wennstrom, A., Ericson, L., Miller, W. J., and Morton, R. 1992. Density-dependent mortality in Pinus sylvestris caused by the snow blight pathogen Phacidium infestan. Oecologia 90:74-79.

12. Chester, K. S. 1946. The Nature and Prevention of Cereal Rusts as Exemplified in the Leaf Rust of Wheat. 2nd ed. Chronica Botanica, Waltham, MA.

13. Chin, K. M., and Wolfe, M. S. 1984. The spread of Erysiphe graminis $\mathrm{f}$. sp. hordei in mixtures of barley varieties. Plant Pathol. 33:89-100.

14. Darwinkel, A. 1978. Patterns of tillering and grain production of winter wheat at a wide range of plant densities. Neth. J. Agric. Sci. 26:383-398.
15. Darwinkel, A. 1980. Ear development and formation of grain yield in winter wheat. Neth. J. Agric. Sci. 28:156-163.

16. Davies, J. C. 1976. The incidence of rosette disease in groundnut in relation to plant density and its effect on yield. Ann. Appl. Biol. 82:489-501.

17. Finckh, M. R., and Mundt, C. C. 1992. Plant competition and disease in genetically diverse wheat populations. Oecologia 91:82-92.

18. Fitt, B. D. L., and McCartney, H. A. 1986. Spore dispersal in relation to epidemic models. Pages 311-345 in: Plant Disease Epidemiology, Vol. 1. K. J. Leonard and W. E. Fry, eds. Macmillian Publishing Co., New York.

19. Frederick, J. R., and Marshall, H. G. 1985. Grain yield and yield components of soft red winter wheat as affected by management practices. Agron. J. 77:495-499.

20. Harper, J. L. 1977. Population Biology of Plants. Academic Press, London.

21. Leonard, K. J. 1969. Factors affecting rates of stem rust increase in mixed plantings of susceptible and resistant oat varieties. Phytopathology 59:1845-1850.

22. Luthra, J. K., and Rao, M. V. 1979. Escape mechanism operating in multilines and its significance in relation to leaf rust epidemics. Indian $\mathrm{J}$. Genet. Plant Breed. 39:38-49.

23. Mundt, C. C., and Browning, J. A. 1985. Development of crown rust epidemics in genetically diverse oat populations: Effect of genotype unit area. Phytopathology 75:607-610.

24. Mundt, C. C., and Leonard, K. J. 1986. Analysis of factors affecting disease increase and spread in mixtures of immune and susceptible plants in computer-simulated epidemics. Phytopathology 76:832-840.

25. Plotkin, M. J. 1993. Tales of a Shaman's Apprentice: An Ethnobotanist Searches for New Medicine in the Amazon Rain Forest. Viking Penguin, New York.

26. Power, A. G. 1991. Virus spread and vector dynamics in genetically diverse plant populations. Ecology 72:232-241.

27. Scott, M. R. 1956. Studies on the biology of Sclerotium cepivorum Berk. II. The spread of white rot from plant to plant. Ann. Appl. Biol. 44:584-589.

28. Shah, S. A., Harrison, S. A., Boquet, D. J., Colyer, P. D., and Moore, S. H. 1994. Management effects on yield and yield components of lateplanted wheat. Crop Sci. 34:1298-1303.

29. Shaner, G. 1973. Evaluation of slow-mildewing resistance of Knox wheat in the field. Phytopathology 63:867-872.

30. Stanton, M. L. 1983. Spatial patterns in the plant community and their effects upon insect search. Pages 125-157 in: Host Seeking Behavior and Mechanisms. S. Ahmad, ed. Academic Press, New York.

31. Strandberg, J. O., and White, J. M. 1978. Cercospora apii damage of celery-Effects of plant spacing and growth on raised beds. Phytopathology 68:223-226.

32. Thurston, H. D. 1991. Sustainable Practices for Plant Disease Management in Traditional Farming Systems. Westview Press, Boulder, CO.

33. Tomerlin, J. R., and Howell, T. A. 1988. DISTRAIN: A computer program for training people to estimate disease severity on cereal leaves. Plant Dis. 72:455-459.

34. Van Rheenen, H. A., Hasselbach, O. E., and Muigai, S. G. S. 1981. The effect of growing beans together with maize on the incidence of bean diseases and pests. Neth. J. Plant Pathol. 87:193-199.

35. Wolfe, M. S. 1985. The current status and prospects of multiline cultivars and variety mixtures for disease resistance. Annu. Rev. Phytopathol. 23:251-273

36. Yoda, K., Kira, T., Ogawa, H., and Hozumi, K. 1963. Self thinning in overcrowded pure stands under cultivated and natural conditions. J. Biol. Osaka City Univ. 14:107-129. 